\author{
ANNA MUSZYŃSKA \\ ORCID: 0000-0003-2008-382X \\ Uniwersytet Wrocławski \\ Katedra Prawa Karnego Materialnego
}

\title{
UWAGI NA TEMAT KIERUNKU ZMIAN PRAWA KARNEGO MATERIALNEGO W LATACH 2015-2019
}

\begin{abstract}
Abstrakt: Autorka opracowania prezentuje zasadnicze założenia reformatorskie przeprowadzone w ramach kodyfikacji karnej z 1997 roku. Odnosi się do najbardziej rozległych nowelizacji kodeksu karnego, które weszły w życie z dniem 1 lipca 2015 roku oraz do zmian przewidzianych w ustawie z dnia 13 czerwca 2019 roku, skierowanej przez Prezydenta RP w dniu 28 czerwca 2019 roku do Trybunału Konstytucyjnego. W toku rozważań autorka odwołuje się do najczęściej dyskutowanych regulacji, które wskazują na kształtowanie się nowej filozofii karania. Poważne zastrzeżenia, jej zdaniem, budzi kierunek dokonanych zmian, które istotnie zwiększają punitywność systemu karnego, wytyczają kierunek polityki karnej zmierzający do wyraźnego zaostrzenia represji karnej. Autorka akcentuje niespójność systemowych rozwiązań, podaje w wątpliwość ich zasadność i wyraża dezaprobatę dla przyjętej ostatnio strategii rozwoju prawa karnego.
\end{abstract}

Słowa kluczowe: przestępstwo, sankcja, ustawowe granice kary, punitywność, kompensacja, polityka karna

Dynamiczne zmiany w zakresie obowiązującego prawa karnego, zarówno ilościowe, jak i jakościowe, niewątpliwie dają asumpt do zastanowienia się nad kierunkiem rozwoju tego prawa. Prowadzone od wejścia w życie kodeksu karnego z 1997 roku $^{1}$ polemiki w tym zakresie uwzględniają rozmaity kontekst, począwszy od ogólnego nakreślenia modelu ustawowej polityki karnej, przez ocenę prawa w działaniu, po uszczegółowioną prezentację wybranych rozwiązań normatywnych wskazujących na nową filozofię karania. Włączając się w nurt dyskusji o kolejnych nowelizacjach, ich charakterze i konsekwencjach, odzwierciedlających kierunek rozwoju, należy przybliżyć najbardziej znaczące z nich, jako te, które nakreślają szerszą perspektywę transformacji prawa karnego. Nie chodzi przy tym o szczegółową analizę regulacji, lecz wybiórcze wskazanie naj-

${ }^{1}$ Ustawa z dnia 6 września 1997 roku — Kodeks karny (tekst jedn. Dz.U. z 2019 r. poz. 1950 ze zm.), która weszła w życie 1 września 1998 roku. 
bardziej znamiennych modyfikacji, które pozwalają ustalić, czy mamy wciąż do czynienia z nowelizacją prawa karnego utrzymaną w konwencji jednego modelu karania, czy może rekodyfikacją albo nową kodyfikacją karną odpowiadającą jakiejś współczesnej myśli karnistycznej. Warto podkreślić, że kodeks karny z 1997 roku poddawany był intensywnym działaniom reformatorskim. Od początku jego obowiązywania był kilkadziesiąt razy nowelizowany ${ }^{2}$. Jednakże do najbardziej znaczących należy zaliczyć nowelizacje wprowadzone ustawą z dnia 20 lutego 2015 roku $^{3}$ i ustawą z dnia 20 marca 2015 roku$^{4}$, które zasadniczo zmodyfikowały system środków reakcji na przestępstwo. Ustawodawca, nie poprzestając na nich, przygotował dalsze, rozległe zmiany, które zawarł tym razem w ustawie z dnia 13 czerwca 2019 roku $^{5}$. Należy zaznaczyć przy tym, że wyjątkowa miara wyzwań interpretacyjnych wywołanych wskazanymi nowelizacjami wyłoniła się w warunkach reformy wielopłaszczyznowej, obejmującej głęboką przebudowę modelu procesu karnego i istotne zmiany w prawie karnym wykonawczym.

Powracając do początków obowiązywania kodeksu karnego z 1997 roku, należy podkreślić, że kształtował się on pod hasłem racjonalizacji instytucji prawa karnego ${ }^{6}$ i osłabienia jego punitywności. Przyjęty co do założeń teoretycznych kierunek liberalizacji prawa był dość powszechnie aprobowany, problematyczne okazało się natomiast oznaczenie jego granic ${ }^{7}$.

Stosunkowo wcześnie pojawiły się głosy krytyki ${ }^{8}$. Potrzebę zmian kodeksu karnego upatrywano w wadliwej strukturze orzekanych kar, przejawiającej się w marginalizacji kar o charakterze wolnościowym, oraz innych niedostatkach

2 Zestawienie nowelizacji zob. M. Olężałek, Racjonalny czy nieracjonalny ustawodawca? Uwagi na tle polskiego ustawodawstwa ze szczególnym uwzględnieniem prawa karnego sensu largo, [w:] O stabilności kodeksu karnego w świetle realiów. Księga jubileuszowa Profesora Stanisława Hoca, t. 2, red. D. Mucha, Opole 2018, s. 96-101.

${ }^{3}$ Ustawa z dnia 20 lutego 2015 roku o zmianie ustawy — Kodeks karny oraz niektórych innych ustaw (Dz.U. z 2015 r. poz. 396), która weszła w życie 1 lipca 2015 roku.

${ }^{4}$ Ustawa z dnia 20 marca 2015 roku o zmianie ustawy - Kodeks karny oraz niektórych innych ustaw (Dz.U. z 2015 r. poz. 541), która weszła w życie 18 maja 2015 roku.

5 Ustawa z dnia 13 czerwca 2019 roku o zmianie ustawy - Kodeks karny oraz niektórych innych ustaw, druk nr 3451. Ustawa 28 czerwca 2019 roku skierowana została przez Prezydenta RP do Trybunału Konstytucyjnego w trybie kontroli prewencyjnej ze względu na zastrzeżenia co do dochowania konstytucyjnych standardów procesu legislacyjnego.

6 T. Kaczmarek, Nowy polski kodeks karny i jego aksjologiczne oraz kryminalno-polityczne założenia, [w:] idem, Rozważania o przestępstwie i karze. Wybór prac z okresu 40-lecia naukowej twórczości, Warszawa 2006, s. 784-799.

7 J. Skupiński, Problem reformy prawa karnego: nowelizacja czy rekodyfikacja, [w:] Aktualne problemy prawa karnego. Ksiegga pamiatkowa z okazji jubileuszu 70. urodzin Profesora Andrzeja J. Szwarca, red. Ł. Pohl, Poznań 2009, s. 543-550; M. Melezini, Represyjność polityki karnej w okresie obowiąywania nowej kodyfikacji karnej, [w:] Nauki penalne wobec problemów współczesnej przestępczości. Księga jubileuszowa z okazji 70. rocznicy urodzin Profesora Andrzeja Gaberle, red. K. Krajewski, Warszawa 2007, s. 487-493.

${ }^{8}$ K. Daszkiewicz, Kodeks karny — ,liberalny czy racjonalny”?, [w:] Teoretyczne i praktyczne problemy wspótczesnego prawa karnego. Księa jubileuszowa dedykowana Profesorowi 
przepisów utrudniających prawidłowe funkcjonowanie systemu odpowiedzialności karnej, których rzeczywistym wymiarem była między innymi wysoka populacja więzień.

W wyniku nowelizacji z 2015 roku zasadniczo przebudowano prawie wszystkie rozdziały części ogólnej kodeksu karnego normujące problematykę kar i innych środków reakcji na przestępstwo. Ogólnym celem była zmiana struktury orzekanych kar w kierunku ograniczenia zakresu stosowania kary pozbawienia wolności, w tym zwłaszcza z warunkowym zawieszeniem jej wykonania, na rzecz stosowania kar nieizolacyjnych, to jest grzywny oraz kary ograniczenia wolności, które odtąd miały być podstawowym środkiem reakcji na przestępstwa drobne i o średnim ciężarze gatunkowym. Porządkując zmiany nowelizacyjne, do najważniejszych z nich, mających doprowadzić do realizacji założonych celów kryminalnopolitycznych, należało zaliczyć: 1. radykalne ograniczenie możliwości stosowania kary pozbawienia wolności z warunkowym zawieszeniem jej wykonania; 2. wprowadzenie możliwości orzeczenia kary grzywny oraz kary ograniczenia wolności w wypadku wszystkich przestępstw zagrożonych karą pozbawienia wolności nieprzekraczającą 8 lat; 3. przekształcenie zasady ultima ratio tak zwanej bezwzględnej kary pozbawienia wolności w zasadę ultima ratio kary pozbawienia wolności w ogóle; 4. uchylenie art. 58 § 2 k.k., stanowiącego formalną przeszkodę orzekania grzywny ze względu na sytuację majątkową sprawcy; 5 . modyfikację kształtu prawnego kary ograniczenia wolności; 6 . wprowadzenie tak zwanej kary mieszanej jako instrumentu reakcji prawnokarnej; 7. rozszerzenie możliwości stosowania warunkowego umorzenia postępowania karnego na przestępstwa zagrożone karą pozbawienia wolności nieprzekraczającą 5 lat ${ }^{9}$. W zakresie części szczególnej nowelizacja, która weszła w życie z dniem 1 lipca 2015 roku, nie była nazbyt obszerna, miała raczej charakter dostosowawczy, nakierowany na synchronizację niektórych przepisów ze zmianami w części ogólnej.

Jako jeden z pierwszych, a zarazem kluczowych dla reformy z 2015 roku, zarysował się cel ukierunkowany na stworzenie nowego modelu sankcji przewidzianych za popełnienie przestępstwa. Próba jego realizacji nastąpiła przez ograniczenie wykorzystania w praktyce orzeczniczej instrumentu probacyjnego, jakim jest warunkowe zawieszenie wykonania kary pozbawienia wolności. Działania podjęte w tym kierunku wynikały z analizy statystycznej wskazującej nadmierne stosowanie wspomnianej konstrukcji prawnej, która ostatecznie uzyskała najwyższą pozycję w wymiarze kar. Eliminacja zaistniałego stanu rzeczy nastąpiła przez modyfikację ogólnych przesłanek warunkowego zawieszenia wykonania kary pozbawienia wol-

Tadeuszowi Bojarskiemu, red. A. Michalska-Warias, I. Nowikowski, J. Piórkowska-Flieger, Lublin 2011, s. 58-65.

9 Zob. obszerniej M. Melezini, Tendencje w polityce karnej po reformie prawa karnego z 2015 r., [w:] Racjonalna sankcja karna w systemie prawa, red. P. Góralski, A. Muszyńska, Warszawa 2019, s. 123-135. Szerokiemu omówieniu zagadnień reformy prawa karnego 2015 roku poświęcono całościowo opracowania zamieszczone w czasopiśmie „Palestra” 2015, z. 7-8. 
ności w art. $69 \S 1$ k.k., określającym fakultatywne stosowanie tej instytucji w razie orzeczenia kary pozbawienia wolności w wymiarze nieprzekraczającym roku, jeżeli sprawca nie był w czasie popełnienia czynu skazany na karę pozbawienia wolności. Obniżenie, w stosunku do pierwotnego rozwiązania, progu kary orzeczonej z 2 lat do roku oraz włączenie warunku quasi-recydywy ewidentnie ograniczyło możliwość stosowania tego rodzaju reakcji karnej. W zaistniałej sytuacji naturalną konsekwencją stało się przekierowanie decyzyjności organu orzekającego w stronę częstszego wyboru dolegliwości w postaci kary pozbawienia wolności bez warunkowego jej zawieszenia, zwłaszcza kary krótkoterminowej. Mając na uwadze, że niejednokrotnie mogła ona okazać się dolegliwością niewspółmierną, nieodzowne okazało się stworzenie możliwości alternatywnych, które prowadzą do częstszego stosowania instrumentów już istniejących, ewentualnie poszukiwania modyfikacji wypełniających obszar dotychczas zajęty orzeczniczo przez karę pozbawienia wolności z warunkowym zawieszeniem jej wykonania. W ramach alternatywnych sposobów reakcji na przestępstwa ustawodawca zaoferował nowe rozwiązania przewidziane w art. 37a k.k. oraz art. 37b k.k. Przepisem art. 37a k.k. prawodawca wprowadził możliwość orzeczenia kary grzywny lub ograniczenia wolności w wypadku przypisania odpowiedzialności karnej za przestępstwo zagrożone karą pozbawiania wolności nieprzekraczającą 8 lat. Przyjęte rozwiązanie bez wątpienia poszerzyło wachlarz reakcji na czyn zabroniony. Podobnie należy spojrzeć na novum w polskim systemie prawa karnego, a mianowicie konstrukcję art. 37b k.k., przewidującego możliwość orzeczenia wobec sprawcy występku jednocześnie krótkoterminowej kary pozbawienia wolności oraz kary ograniczenia wolności. Idąc dalej, można wskazać, że ustawodawca położył wyraźny akcent na prymat kar nieizolacyjnych. $\mathrm{O}$ ile w odniesieniu do kary grzywny, poza przywołanym już rozwiązaniem $\mathrm{z}$ art. 37a k.k., zmianami w zakresie kary łącznej grzywny oraz uchyleniem art. 58 $\S 2$ k.k. określającego dyrektywy wymiaru grzywny, ustawodawca nie przewidział znaczących modyfikacji, o tyle przedstawił nowe ujęcie kary ograniczenia wolności. Po nowelizacji kara ograniczenia wolności zmieniła charakter, mimo że w dalszym ciągu jej treść składa się z dwóch elementów obligatoryjnych, a także możliwości orzeczenia oprócz tej kary określonych obowiązków. Poza dotychczasową tradycyjną formą potrącenia i nieodpłatnej kontrolowanej pracy na cele społeczne kara ograniczenia wolności została wzbogacona o określone w ustawie obowiązki, które mogły przyjąć samoistną i jedyną postać tej kary, a także obowiązek pozostawania w miejscu pobytu z zastosowaniem dozoru elektronicznego. Ustawodawca przewidział również kumulację różnych postaci kary ograniczenia wolności. Nowa formuła kary ograniczenia wolności przybrała w ten sposób realną postać alternatywy dla kary grzywny w wypadkach, gdy jej orzeczenie byłoby nieracjonalne, chociażby z powodu sytuacji finansowej sprawcy, a kary pozbawienia wolności, gdy ta okazalaby się nadmiernie surowa.

Drugim istotnym kompleksem zmian, determinującym charakter nowelizacji z 2015 roku, była modyfikacja zasad kompensaty szkód wyrządzonych przestęp- 
stwem i w rezultacie wzmocnienie pozycji pokrzywdzonego. Nowelizacja w tym zakresie ukierunkowana została przede wszystkim na wyeliminowanie trudności związanych z dochodzeniem obowiązku naprawienia szkody, zadośćuczynienia za krzywdę, nawiązki oraz orzekaniem różnych odmian przepadku. Przywołana modyfikacja mieści się w szerszym nurcie związanym z realizacją idei sprawiedliwości naprawczej i propagowaną współcześnie ideologią non intervention ${ }^{10}$. Generalizując, można stwierdzić, że sztandarowym hasłem wymienionych ideologii jest dążenie do zwiększenia znaczenia polubownego rozwiązania konfliktu społecznego wynikłego z popełnienia przestępstwa, zwłaszcza poprzez negocjacje, pojednanie czy ugodę. Idąc dalej, wypada przypomnieć, że z takim założeniem łączą się propozycje ograniczenia interwencji państwa w zakresie prawa karania, odstępowania od tradycyjnych form karania na rzecz rozstrzygnięć alternatywnych, w tym pozasądowej probacji, procedur pojednawczych i naprawczych. Obecnie ustąpienie w określonym zakresie pola sprawiedliwości naprawczej odbywa się „na warunkach” retrybutywizmu, oznacza to dokonywanie oceny wagi czynu z perspektywy interesu państwa. Im mniejszy interes publiczny w wymierzeniu kary, tym większy osiągamy zakres zastosowania postępowania naprawczego jako formy reakcji na przestępstwo czy nawet możność poprzestania jedynie na tego rodzaju reakcji. Urzeczywistnienie wspomnianych idei może przybierać różne postaci. W płaszczyźnie procesowej nacisk kładzie się przede wszystkim na optymalne ukształtowanie praw i gwarancji pokrzywdzonego, rozwój mediacji i konstrukcji konsensualnych sposobów rozwiązywania sporu. Z kolei w sferze prawa karnego materialnego znaczące miejsce wyznacza się środkom o charakterze kompensacyjnym. W rozwiązaniach ustawy karnej można wręcz zaobserwować pewną ewolucję — od ostrożnego uwzględniania naprawienia szkody jako okoliczności mającej wpływ na wymiar kary do aprobowania obowiązku naprawienia szkody jako samodzielnego środka karnego, a obecnie środka kompensacyjnego. Porządkując ostatecznie ten wątek nowelizacyjny, wskazać trzeba, że wprowadzona ustawą z 20 lutego 2015 roku zmiana w zakresie obowiązku naprawienia szkody była zapowiedzią usunięcia dotychczasowych wątpliwości powstałych wokół dyskusji o prawnym charakterze obowiązku, jak i wybranych, kontrowersyjnych aspektach jego orzeczniczego wykorzystania, związanych przykładowo z możliwością solidarnego orzekania obowiązku, niezasądzania odsetek, różnicowania sytuacji pokrzywdzonych na etapie wykonawczym w zależności od podstaw prawnych obowiązku. W ustawie nastąpiła rezygnacja $\mathrm{z}$ hybrydowej konstrukcji obowiązku naprawienia szkody jako środka karnego i przyjęcie wyraźnie deklarowanego kierunku cywilnoprawnego, odpowiadającego jego istocie. Ustawodawca „wyjął” obowiązek naprawienia szkody z katalogu środków karnych i umieścił

10 I. Zgoliński, Kierunki rozwoju polskiego prawa karnego w świetle jego reformy, [w:] Reforma prawa karnego materialnego i procesowego z 2015 r. Wybrane zagadnienia, red. D. Kala, I. Zgoliński, Warszawa 2015, s. 128 n. 
go w nowym rozdziale Va, zatytułowanym „Przepadek i środki kompensacyjne”, wskazując w uzasadnieniu do nowelizacji, że obowiązkowi temu nadaje kształt cywilnoprawny. Działania ustawodawcy były zresztą nieco bardziej zdecydowane i w rezultacie doprowadziły do usunięcia z zakresu prawa karnego niektórych podstaw naprawienia szkody związanych z możliwością wytoczenia powództwa adhezyjnego czy zasądzenia odszkodowania z urzędu.

Rozwiązania prawa karnego naprawczego zostały uzupełnione także w regulacji art. 59a k.k. ${ }^{11}$ o dość innowacyjnym charakterze. Ustawodawca, wzmacniając rolę instrumentów restytucyjnych, dopuścił alternatywny dla skazania sposób zakończenia postępowania karnego w postaci możliwości bezwarunkowego umorzenia postępowania w zamian za zaspokojenie roszczeń pokrzywdzonego. Decyzja następowała po spełnieniu określonych $\mathrm{w}$ ustawie przesłanek, $\mathrm{w}$ razie pojednania i naprawienia szkody pokrzywdzonemu, który przed rozpoczęciem przewodu sądowego wystąpił z wnioskiem o umorzenie. Umorzenie kompensacyjne, nazywane też wnioskowym, od samego początku budziło wiele zastrzeżeń co do przyjętej konstrukcji i konsekwencji ${ }^{12}$, niemniej jednak komponowało się z nową filozofią procedury karnej ograniczającą aktywność organów wymiaru sprawiedliwości, jak też wyraźnie uwzględniającą wolę stron, które doszły do porozumienia i zaakceptowały określony sposób zakończenia sprawy karnej. Jako instytucja umożliwiająca zaspokojenie roszczeń pokrzywdzonego, a przy tym pozwalająca sprawcy, który naprawił szkodę, na odniesienie pewnych korzyści procesowych stwarzała też szansę sprawnego rozpoznania spraw i zminimalizowania kosztów postępowania, w szczególności w sprawach o drobne przestępstwa. Jednakże ze względu na zmianę stanowiska ustawodawcy odnośnie do wizji modelu karania instytucja z art. 59a k.k. nie została należycie przepracowana i zweryfikowana ani w kontekście ujęcia normatywnego, ani w praktyce orzeczniczej ${ }^{13}$. Ze względu na wyrażaną obawę zagrożenia realizacji celów kary i postępowania karnego oraz zbytnie ryzyko prywatyzacji procesu poprzez stwarzanie majętnym sprawcom sytuacji wykupienia się od odpowiedzialności karnej instytucja ta szybko została wyeliminowana z porządku prawnego ${ }^{14}$.

11 Art. 59a wprowadzony ustawą z dnia 27 września 2013 roku o zmianie ustawy — Kodeks postępowania karnego oraz niektórych innych ustaw (Dz.U. z 2013 r. poz. 1247) w brzmieniu nadanym ustawą z dnia 20 lutego 2015 roku o zmianie ustawy - Kodeks karny oraz niektórych innych ustaw (Dz.U z 2015 r. poz. 396), który wszedł w życie 1 lipca 2015 roku.

12 A. Orfin, Rola i znaczenie instytucji umorzenia kompensacyjnego uregulowanego $w$ przepisie art. 59 a k.k., [w:] Konsensualizm i kompensacja a podstawy odpowiedzialności karnej, red. I. Sepioło-Jankowska, Warszawa 2016, s. 255-264; A. Pilch, Umorzenie kompensacyjne w trybie art. 59 a k.k. - wybrane zagadnienia, „Palestra” 2015, z. 7-8, s. 57-64; eadem, Umorzenie postępowania w trybie projektowanego art. 59a k.k., „Państwo i Prawo” 2013, z. 4, s. 94-106.

13 D. Bek, A. Jaworska-Wieloch, O. Sitarz, Ksztattowanie środków penalnych a prawo pokrzywdzonego i sprawcy do samostanowienia, Warszawa 2019, s. 149-156.

14 Art. 59a k.k. obowiązywał od 1 lipca 2015 do 15 kwietnia 2016 roku, został uchylony ustawą z dnia 11 marca 2016 roku o zmianie ustawy - Kodeks postępowania karnego oraz niektórych innych ustaw (Dz.U. z 2016 r. poz. 437 ze zm.). 
Kolejny zakres nowelizacyjny, z 2015 roku, obejmował system środków zabezpieczających, zmuszając do ponownego zwrócenia się w stronę zagadnień związanych z tak zwaną dwutorowością polskiego kodeksu karnego ${ }^{15}$. Niewątpliwie fundamentalne znaczenie miało zweryfikowanie tej części modelu karnego, w której chodzi o właściwe określenie relacji pomiędzy zastosowaniem sankcji karnej a koniecznością leczenia. Poszukując odpowiednich prawnokarnych regulacji, podkreślono nadrzędny cel środków zabezpieczających, to jest ochronę przed sprawcami niebezpiecznymi dla porządku prawnego, realizowany przez izolację, a w dalszej kolejności przez leczenie. Do głosu doszły poglądy eksponujące znaczenie elementu leczniczego ukierunkowanego na usunięcie kryminogennych właściwości sprawcy czy też wyraźnie ukazujące tendencje przyznania, w niektórych sytuacjach, w ramach prawa karnego leczeniu i rehabilitacji prymatu przed represją. Nowelizacja wprowadziła gruntowne zmiany w układzie środków zabezpieczających, który objął całkowicie zmodyfikowany katalog środków. W nowym ujęciu do środków zabezpieczających zaliczono elektroniczną kontrolę miejsca pobytu, terapię, terapię uzależnień, pobyt w szpitalu psychiatrycznym. W porównaniu z uprzednią regulacją wzbogacono katalog o dwa nowe środki: elektroniczną kontrolę miejsca pobytu oraz nakaz określony w art. 39 pkt 2e k.k., zrezygnowano natomiast ze środka w postaci umieszczenia sprawcy w zakładzie karnym, w którym stosuje się szczególne środki lecznicze lub rehabilitacyjne. Istotnym modyfikacjom poddano też unormowania dotyczące środków związanych ze stosowaniem terapii i terapii uzależnień. Zmiany polegały przede wszystkim na nadaniu większości środków zabezpieczających wolnościowego charakteru i wzmocnieniu w ich treści podobieństw do środków probacyjnych. Wyraźnie zaznaczono, że środki te można orzekać tylko wówczas, gdy jest to konieczne, aby zapobiec ponownemu popełnieniu przez sprawcę czynu zabronionego, a pozostałe środki prawne przewidziane w kodeksie lub przepisach innych ustaw nie będą wystarczające do osiągnięcia tego celu.

Ustawodawca, zachowując intensywną aktywność legislacyjną, przygotował w 2019 roku kolejną kompleksową nowelizację kodeksu karnego. Rozległa skala zmian dotyczy tak fundamentalnych dla systemu prawa karnego regulacji, że można uznać, iż wytyczają one odmienny od dotychczasowego kierunek rozwoju prawa karnego, który generalnie zakłada zwiększenie surowości karania ${ }^{16}$. Za-

15 Zob. m.in. P. Góralski, Koncepcja tzw. wolnościowych środków zabezpieczających założenia teoretyczne oraz problemy wyktadni i stosowania w praktyce, [w:] Wspótczesne przeksztatcenia sankcji karnych — zagadnienia teorii, wyktadni i praktyki stosowania, red. P. Góralski, A. Muszyńska, Warszawa 2018, s. 269-296; A. Barczak-Oplustil, Środki zabezpieczajace, [w:] Nowelizacja prawa karnego 2015. Komentarz, red. W. Wróbel, Kraków 2015, s. 671-774; I. Zduński, Nowelizacja środków zabezpieczających w świetle osiagnięć współczesnej psychiatrii, [w:] Reforma prawa karnego..., s.79-113; J. Majewski, Kodeks karny. Komentarz do zmian 2015, Warszawa 2015, s. 347 n.

16 M. Melezini, Problemy reformy prawa karnego. Uwagi na tle ustaw z 13 czerwca 2019 r., [w:] Reforma prawa karnego w latach 2015-2019. Zagadnienia wybrane, red. P. Góralski, A. Muszyńska, Warszawa 2020, w druku. 
proponowane rozwiązania wkraczają w obszar części ogólnej kodeksu karnego, zmieniając zasady odpowiedzialności karnej nieletnich, katalog kar i środków karnych, zasady wymiaru kary grzywny i kary pozbawienia wolności, ogólne dyrektywy sądowego wymiaru kary, środki związane z poddaniem sprawcy próbie, powrotność do przestępstwa, kwestię przedawnienia i definicji niektórych wyrażeń ustawowych. Modyfikacje objęły również część szczególną kodeksu karnego w zakresie zmiany surowości sankcji karnych i konstrukcji poszczególnych typów czynów zabronionych oraz powołania nowych typów czynów zabronionych.

Istotę nowelizacji kodeksu karnego najlepiej oddaje zawarte w uzasadnieniu twierdzenie prawodawcy o potrzebie zwiększenia stopnia punitywności z uwzględnieniem trzech poziomów: pierwszym są zmiany w zakresie surowości sankcji karnych i konstrukcji poszczególnych typów czynów zabronionych, drugim - rozszerzenie instytucji nadzwyczajnego zaostrzenia kary, trzeci zaś dotyczy zmian w ogólnych dyrektywach wymiaru kary ukierunkowanych na wybór bardziej surowej represji karnej ${ }^{17}$.

Nowelizacja przewiduje wprowadzenie istotnych zmian do tak zwanego katalogu kar, a mianowicie rezygnację z kary 25 lat pozbawienia wolności oraz zmianę rodzajowych granic kary pozbawienia wolności, to jest podwyższenie z 15 do 30 lat. W konsekwencji kara 25 lat pozbawienia wolności miałaby utracić swój nadzwyczajny charakter i odrębność rodzajową. Należy jednak podkreślić, że utrzymanie hierarchicznie uporządkowanego katalogu kar pozbawienia wolności w myśl obowiązującego stanu prawnego bądź ewentualne przychylenie się do nowej koncepcji „terminowej” kary pozbawienia wolności od miesiąca do lat 30 jest kwestią zaakceptowania pewnej konwencji. Rozwiązanie zaproponowane w ustawie zmieniającej mogłoby nawet zostać uznane za uzasadnione. Można się spodziewać, że uprościłoby w praktyce realizację zasady indywidualizacji kary przy jej orzekaniu za najcięższe przestępstwa. Trzeba jednak zauważyć, że za dokonanym zabiegiem normatywnym kryje się zgoła inna intencja ustawodawcy — generalne, ideologiczne dążenie do zaostrzenia represji. W tym wypadku niebezpieczeństwo wiąże się z kwestią nieproporcjonalnego i systemowo zakłóconego podnoszenia progów ustawowego zagrożenia za poszczególne przestępstwa określone w części szczególnej. Ustawa, poza „dostosowawczymi”, przewiduje bowiem daleko idące modyfikacje wymiaru kar.

Krytykowana była też propozycja ustawodawcy w zakresie kazuistycznego ukształtowania wymiaru kary grzywny (odpowiednio kary ograniczenia wolności), gdy przestępstwo jest zagrożone zarówno grzywną, jak i karą pozbawienia wolności. Następuje wówczas uzależnienie wysokości grzywny od wysokości zagrożenia karą pozbawienia wolności za dane przestępstwo. Taka ingerencja w zasadę swobodnego uznania sądu w zakresie wymiaru kary nieuchronnie prowadzi

17 Uzasadnienia nowelizacji, s. 1-2, https://www.sejm.gov.pl/Sejm8.nsf/druk.xsp?nr=3451 (dostęp: 15.05.2020). 
do mechanicznego odtwarzania sztucznych ram ustawowych. Za optymalne należy uznać rozwiązanie, według którego następuje wskazanie ram orzekania kary grzywny poprzez określenie dolnej i górnej granicy i pozostawienie sędziemu możliwości kształtowania wymiaru kary grzywny odpowiednio do okoliczności konkretnego wypadku.

$\mathrm{W}$ ustawie dokonano istotnej zmiany treści przepisu art. $53 \S 1 \mathrm{k} . \mathrm{k}$. poprzez odmienne określenie dyrektyw sądowego wymiaru kary. Pamiętać wszakże należy, że dyrektywy kształtują proces wymiaru kary, określając racje karania, chronią przed dowolnością działania sądu. Ich obecne ugruntowane ujęcie jest wynikiem wieloletnich dyskusji i przepracowania rozwiązań poprzedniej kodyfikacji karnej z 1969 roku. Modyfikacje w tym zakresie wiążą się ze zmianami aksjologicznymi i powinny być dokonywane z dużą ostrożnością i rzetelnym uzasadnieniem. Tymczasem zmiana w art. $53 \S 1$ k.k. polega na zastąpieniu dyrektywy w postaci konieczności uwzględnienia „potrzeby w zakresie kształtowania świadomości prawnej społeczeństwa” nową, to jest koniecznością uwzględnienia „celów kary w zakresie społecznego oddziaływania kary", nadto wskazuje na rezygnację z posługiwania się pojęciem „celów wychowawczych kary”. Ustawodawca uzasadnił zmianę nieadekwatnym charakterem pojęcia „,eelów wychowawczych kary”, albowiem prawo karne, jako instrument o charakterze ultima ratio, nie ma w stosunku do jednostek celu wychowawczego, lecz jego zadaniem jest kształtowanie systemu prawnokarnie chronionych zakazów, służących podwyższaniu kosztów zachowania przestępczego, ukierunkowanych na wzmacnianie społecznego oraz jednostkowego przekonania o nieopłacalności zachowań naruszających prawo. Zanegował on obowiązujące ujęcie, proponując koncepcję, która budzi wiele wątpliwości. Jej podstawowym i naczelnym założeniem jest zmiana filozofii karania, ukierunkowanej przede wszystkim na odstraszanie i odwet. Bez należytego uzasadnienia prawodawca neguje istniejący porządek prawny opierający się na dyrektywach sprawiedliwościowych i celowościowych (cel zapobiegawczy i wychowawczy) przy wymierzaniu kary. Proponowany sposób ujęcia dyrektyw sądowego wymiaru kary rodzi niebezpieczeństwo nazbyt arbitralnego działania sądu oraz godzi w dotychczasowe podstawy aksjologiczne, według których odstraszanie jest jednym z elementów karania, jednak nie najważniejszym.

Prawodawca przewidział wiele zmian w zakresie środków związanych z poddaniem sprawcy próbie. W ustawie określono możliwość orzeczenia zakazu warunkowego przedterminowego zwolnienia, jeżeli charakter i okoliczności czynu oraz właściwości osobiste sprawcy wskazują, że jego pozostawanie na wolności spowoduje trwałe zagrożenie życia, zdrowia, wolności lub wolności seksualnej innych osób. Obligatoryjny zakaz pojawia się w wypadku wymierzenia kary dożywotniego pozbawienia wolności sprawcy za czyn popełniony przez niego po prawomocnym skazaniu za inne przestępstwo na karę dożywotniego pozbawienia wolności albo karę pozbawienia wolności na czas nie krótszy niż 20 lat. Przyjęte ujęcie przewiduje zatem, powszechnie krytykowane, bezwzględne dożywotnie 
pozbawienie wolności. Należy podkreślić, że obowiązujące rozwiązania dotyczące kary dożywotniego pozbawienia wolności oraz warunków przedterminowego zwolnienia są wynikiem doświadczeń wypracowanych na gruncie kodeksu karnego z 1932 roku, nadto dyskusji toczących się w czasie przywracania w kodeksie karnym z 1997 roku nowelizacją z 1995 roku kary dożywotniego pozbawienia wolności. Odniesienia do standardów międzynarodowych, wartości konstytucyjnych doprowadziły do ugruntowania stanowiska przeciwstawiającego się bezwzględnemu dożywotniemu pozbawieniu wolności.

Zmiany zawarte w części ogólnej kodeksu karnego dopełniają rozległe modyfikacje rozwiązań części szczególnej. Do najbardziej istotnych należy zaliczyć niewątpliwie te, które polegają na rozszerzeniu zakresu penalizacji przez dodanie nowych typów czynów zabronionych czy kazuistyczne rozwarstwienie typów czynów już istniejących. Porządkując, wyodrębnić można zmiany dotyczące surowości sankcji karnych, konstrukcji poszczególnych przestępstw oraz powołania nowych przestępstw, w szczególności w sferze czynów godzących w życie i zdrowie człowieka, wolność seksualną oraz własność ${ }^{18}$.

Opisane przekształcenia nowelizacyjne pozwalają dokonać ogólnej syntezy założeń odpowiadających przyjętemu kierunkowi rozwoju prawa karnego. Nawet ich pobieżna weryfikacja wskazuje dążenie ustawodawcy do przeprowadzania permanentnych zmian obowiązujących przepisów. Ogólna charakterystyka rudymentarnych regulacji ukazuje ramy proponowanej przez prawodawcę nowej filozofii karania. Z nowelizacji z 2015 roku można odczytać wyraźną preferencję dla kar nieizolacyjnych oraz alternatywnych dla skazania sposobów zakończenia postępowania karnego. Rozwinięcie podstaw kary ograniczenia wolności, zwiększenie możliwości orzeczenia kary grzywny czy ograniczenia wolności zamiast kary izolacyjnej, stworzenie interesującego konglomeratu krótkoterminowej kary pozbawienia wolności z karą ograniczenia wolności z pewnością znacząco poszerza zakres wychowawczego i ekonomicznego oddziaływania na sprawcę, w szczególności gdy mamy na uwadze skazania za przestępstwa drobne i średniej wagi. Widoczne są też tendencje przybierające różne postaci wzmocnienia uprawnień pokrzywdzonego. Uelastycznieniem systemu jest otwarcie na alternatywne rozwiązania, dochodzące do głosu zwłaszcza gdy sprawca pojednał się z pokrzywdzonym i naprawił wyrządzoną przestępstwem szkodę. W prawie karnym materialnym dano szczególnie mocny wyraz postrzeganiu elementów sprawiedliwości naprawczej jako tych, które na trwałe zostały wkomponowane w przyjęty model karania. Tak zakreślony kierunek zmian zasługuje na aprobatę, chociaż towarzyszą temu również istotne obawy. Wynikają one głównie z wątpliwości interpretacyjnych dotyczących różnych regulacji szczegółowych, wymagających dalszej

18 Zob. szerzej opinia w sprawie uchwalonej przez Sejm Rzeczypospolitej Polskiej na 81. posiedzeniu w dniu 16 maja 2019 roku ustawy o zmianie ustawy — Kodeks karny oraz niektórych innych ustaw przygotowana przez Krakowski Instytut Prawa Karnego Fundacja. 
weryfikacji. Szybkość ich tworzenia i wprowadzania w życie niejednokrotnie realnie zagroziła poprawności konstrukcji normatywnej i spójności systemowej. Niewątpliwie jednak pozytywnie jawi się utrzymanie mieszanego charakteru rozwiązań karnych, które nie nawiązują tylko do jednego modelu karania, przez co zachowują otwartość na zróżnicowaną reakcję karną.

Wszechobecna niestabilność rzeczywistości prawnej, warunkowana między innymi czynnikami kulturowymi, politycznymi, znalazła odzwierciedlenie w kolejnej ustawie zmieniającej. Oceniając nowelizację z 2019 roku, dostrzega się zdeprecjonowanie pewnych idei i założeń, które artykułowano w ramach reformatorskich działań z 2015 roku. Można wyrazić uzasadnioną obawę, że w tym wypadku doszło do dość instrumentalnego ukształtowania prawa karnego. Tymczasem przyjęcie wskazanych rozwiązań nie legitymuje się wystarczającym uzasadnieniem, nie znajduje też bezpośredniego źródła w bieżącym stanie przestępczości czy analizie praktyki orzeczniczej. Szczególnie niepokojące wydaje się ograniczenie możliwości stosowania instytucji sądowego wymiaru kary, chociażby poprzez sztywne wyznaczanie granic sankcji, czy wprowadzanie mechanizmów obligatoryjnych. Zmiany zawarte w nowelizacji kodeksu karnego w zakresie systemu reakcji karnej, zaostrzenia sankcji i ich usztywnienia, modyfikacji typów czynów zabronionych, przy jednoczesnym znacznym ograniczeniu swobody działania sądu, spowodowały, że został ukształtowany nowy model karania o jednoznacznie represyjnym wydźwięku.

\title{
REMARKS ON THE DIRECTION OF CHANGES OF SUBSTANTIVE CRIMINAL LAW IN THE YEARS 2015-2019
}

\author{
Summary
}

The author of the study presents the main assumptions carried out under the penal codification of 1997. She refers to the most extensive amendments of the Penal Code that entered into force on 1st July 2015 and also to the amendments provided for in the Act of 13th June 2019, that were referred by the President of the Republic of Poland to the Constitutional Tribunal on 28th June 2019. In the course of considerations, the author refers to the most frequently discussed regulations, that point out the formation of a new philosophy of punishment. She has reservations about the direction of the changes that significantly increase the range of punitive measures of the penal system and set the direction of penal policy aimed at a distinct tightening of criminal repression. The author emphasises the inconsistency of system solutions, casts doubt on their legitimacy and expresses disapproval regarding the recently adopted strategy for the development of penal law.

Keywords: crime, sanction, statutory limits of punishment, punitive measures, compensation, penal policy 


\section{BIBLIOGRAFIA}

Barczak-Oplustil A., Środki zabezpieczajace, [w:] Nowelizacja prawa karnego 2015. Komentarz, red. W. Wróbel, Kraków 2015.

Bek D., Jaworska-Wieloch A., Sitarz O., Ksztattowanie środków penalnych a prawo pokrzywdzonego i sprawcy do samostanowienia, Warszawa 2019.

Daszkiewicz K., Kodeks karny — , liberalny czy racjonalny”?, [w:] Teoretyczne i praktyczne problemy współczesnego prawa karnego. Ksiega jubileuszowa dedykowana Profesorowi Tadeuszowi Bojarskiemu, red. A. Michalska-Warias, I. Nowikowski, J. Piórkowska-Flieger, Lublin 2011.

Góralski P., Koncepcja tzw. wolnościowych środków zabezpieczajacych — założenia teoretyczne oraz problemy wyktadni i stosowania w praktyce, [w:] Wspótczesne przeksztatcenia sankcji karnych — zagadnienia teorii, wyktadni i praktyki stosowania, red. P. Góralski, A. Muszyńska, Warszawa 2018.

Kaczmarek T., Nowy polski kodeks karny i jego aksjologiczne oraz kryminalno-polityczne założenia, [w:] idem, Rozważania o przestępstwie i karze. Wybór prac z okresu 40-lecia naukowej twórczości, Warszawa 2006.

Majewski J., Kodeks karny. Komentarz do zmian 2015, Warszawa 2015.

Melezini M., Problemy reformy prawa karnego. Uwagi na tle ustaw z 13 czerwca 2019 r., [w:] Reforma prawa karnego w latach 2015-2019. Zagadnienia wybrane, red. P. Góralski, A. Muszyńska, Warszawa 2020, w druku.

Melezini M., Represyjność polityki karnej w okresie obowiazywania nowej kodyfikacji karnej, [w:] Nauki penalne wobec problemów wspótczesnej przestępczości. Ksiega jubileuszowa z okazji 70. rocznicy urodzin Profesora Andrzeja Gaberle, red. K. Krajewski, Warszawa 2007.

Melezini M., Tendencje w polityce karnej po reformie prawa karnego z 2015 r., [w:] Racjonalna sankcja karna w systemie prawa, red. P. Góralski, A. Muszyńska, Warszawa 2019.

Olężałek M., Racjonalny czy nieracjonalny ustawodawca? Uwagi na tle polskiego ustawodawstwa ze szczególnym uwzględnieniem prawa karnego sensu largo, [w:] O stabilności kodeksu karnego w świetle realiów. Księga jubileuszowa Profesora Stanisława Hoca, t. 2, red. D. Mucha, Opole 2018.

Orfin A., Rola i znaczenie instytucji umorzenia kompensacyjnego uregulowanego w przepisie art. 59 a k.k., [w:] Konsensualizm i kompensacja a podstawy odpowiedzialności karnej, red. I. Sepioło-Jankowska, Warszawa 2016.

Pilch A., Umorzenie kompensacyjne w trybie art. 59a k.k. — wybrane zagadnienia, „Palestra” 2015, z. 7-8.

Pilch A., Umorzenie postępowania w trybie projektowanego art. 59a k.k., „Państwo i Prawo” 2013, z. 4.

Skupiński J., Problem reformy prawa karnego: nowelizacja czy rekodyfikacja, [w:] Aktualne problemy prawa karnego. Ksiega pamiatkowa z okazji jubileuszu 70. urodzin Profesora Andrzeja J. Szwarca, red. Ł. Pohl, Poznań 2009.

Zduński I., Nowelizacja środków zabezpieczajacych w świetle osiagnięć wspótczesnej psychiatrii, [w:] Reforma prawa karnego materialnego i procesowego z 2015 r. Wybrane zagadnienia, red. D. Kala, I. Zgoliński, Warszawa 2015.

Zgoliński I., Kierunki rozwoju polskiego prawa karnego w świetle jego reformy, [w:] Reforma prawa karnego materialnego i procesowego z 2015 r. Wybrane zagadnienia, red. D. Kala, I. Zgoliński, Warszawa 2015. 